\title{
Candidate gene markers associated with somatotropic axis and milk selection is
}

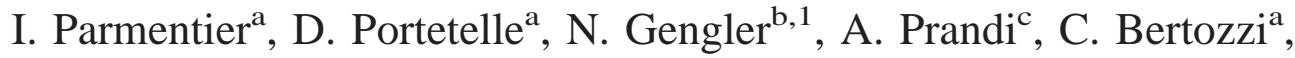 \\ L. Vleurick ${ }^{\mathrm{a}}$, R. Gilson ${ }^{\mathrm{d}}, \mathrm{R}$. Renaville ${ }^{\mathrm{a}, *}$ \\ ${ }^{a}$ Biology and Biochemistry Applied Department, Gembloux Agricultural University, 5030 Gembloux, Belgium \\ ${ }^{\mathrm{b}}$ Animal Science Unit, Gembloux Agricultural University, 5030 Gembloux, Belgium \\ ${ }^{\mathrm{c}}$ University of Udine, 33100 Udine, Italy \\ ${ }^{\mathrm{d} S e m e x ~ B e l g i u m,} 4920$ Sougnez-Remouchamps, Belgium
}

Received 5 February 1999; accepted 5 February 1999

\begin{abstract}
One of the obstacles to progress in dairy cattle selection is that milk production traits are only expressed after the first calving. However, the use of the quantitative trait loci (QTL) technology will improve the efficiency of dairy industry with a positive image for the consumers. QTL are part of the genome showing a preponderant action and explaining the major part of variation of the trait production. At the present time, the two major strategies developed to detect such QTL are the candidate gene approach and the positional genetics approach. The somatotropic axis contains the most promising candidates in this respect, as it strongly regulates milk production. Then, the identification of favorable QTL associated with the somatotropic axis that are significantly correlated with genetic merits for milk production could lead to more effective selection programs. (C) 1999 Elsevier Science Inc. All rights reserved.
\end{abstract}

Keywords: Gene markers; Bovine; Milk; Selection; Somototropic axis

מ This study was supported by a grant from the Belgian Ministry of Medium and Small Enterprises and Agriculture (\# 5859).

${ }^{1}$ Nicolas Gengler is presently Research Team Leader of the Belgian National Fund for Scientific Research, Brussels, Belgium.

* Corresponding author. Tel.: +32-81-622418; fax: +32-81-613888.

E-mail address: renaville.r@fsagx.ac.be (R. Renaville) 


\section{Introduction}

Most economically important traits of dairy cattle are determined by the additional effects of nutritional, environmental, and genetic factors.

By selecting the best performing animals on phenotypic variations (milk, fat, or protein yield) as reproducers, breeders have increased the frequency of favorable alleles influencing the interesting traits. Moreover, in dairy cattle, genetic progress is essentially based on the use of genetically superior sires whose identification requires time (5-6 years) and money $(1,000,000$ US\$). Furthermore, the exact molecular nature of the target genes remains essentially unknown, particularly for production traits that are often controlled by a pool of genes.

With the advances in molecular biology, the identification of the genes underlying livestock production traits-called quantitative trait loci (QTL) - is now possible and is likely to lead to more efficient breeding programs. For selection programs, the benefits of identification of QTL are threefold: first, they can increase the accuracy of selection by providing more information on an animal's breeding value (1); second, they can be identified at earlier stages of life (embryo or neonate) and then be used to decrease the generation interval (2); and finally, they can be used to increase the selection differential by allowing preselection among larger numbers of candidates for later selection (3).

Although a number of strategies can be envisaged to identify candidate gene markers, essentially two approaches are presently developed to estimate the favorable QTL implicated in a specific production trait. The first method, the positional cloning, consists of the localization of the genes of interest using marker-QTL associations covering the whole genome. This approach can be divided in the following steps: 1) identification of chromosomal regions containing QTL of interest $(10-20 \mathrm{cM}), 2)$ specification of QTL location within these regions $(5 \mathrm{cM}), 3)$ identification of markers in tight linkage to the QTL (1-2 $\mathrm{cM}$ ), and 4) identification of potential candidate genes in this region. The positional genetics approach is based on mapping QTL to progressively narrower chromosomal regions, using a battery of microsatellite markers, until suitable candidate genes are identified. Based on the maximum likelihood multilocus linkage analysis that accounts for variance heterogeneity of the phenotypes, different authors reported the presence of QTL affecting milk yield and composition on numerous chromosome regions including chromosomes 1, 2, 5, 6, 9, 10, 14, $16,18,20$, and 23 ( $\mathrm{P}<0.05$ to $\mathrm{P}<0.00001)$ [4-6]. On the other hand, markers with effects on somatic cell score were located on chromosomes 5, 22, and $23(\mathrm{P}<0.005)$ [6]. In this strategy, the next step of research is the chromosomal microdissection of target-specific areas of the involved chromosome and then identification of the actual underlying genes. However, the informativeness of the family material may likely become a limiting factor for finemapping efforts [2].

The second strategy uses the candidate gene approach. This approach consists of the study of different genes potentially involved in the physiological process (e.g., milk proteins synthesis) and to determine for each gene, the allele that results in the interesting phenotype (e.g., rennet coagulation properties). Based on the knowledge of the genetic control of the studied physiological process (e.g., role of the somatotropic axis in regulation of lactation), the identification of polymorphic sites and the evaluation of the allelic differences of the candidate genes, among animals of different phenotypic merits, offer potential for easy 
identification of gene markers associated with phenotypic merit. Polymorphisms may affect directly gene expression by changing splicing of RNA, stability of RNA, rate and regulation of gene transcription, or amino acid sequence of the gene product.

Various studies have shown that a number of single genes associated with mammary growth, development, and function are excellent candidates for linkage relationships with quantitative traits of economic importance. Among the putative candidate genes, the milk protein loci have been studied most extensively, and a number of excellent reviews described the general subject of milk protein genetic polymorphism and its association with milk, fat and protein yields, milk composition, heat coagulation of milk, or rennet coagulation properties [7-9].

As reviewed in this special issue by Bauman [10] and Baldi [11], administration of recombinant growth hormone $(\mathrm{GH})$ to dairy animals dramatically increases milk production and demonstrates the critical role of the somatotropic axis in regulation of lactation. Also, this mini-review focuses on the possible relationships between candidate genes, associated with the somatotropic axis, and quantitative and qualitative milk synthesis.

\section{GH plasma levels and milk selection}

Essentially under the control of the hypothalamic GH-releasing factor (GHRH) and somatostatin (SRIH) GH has a tissue-specific action that can be direct through GH receptor (GHR) or indirect via insulin-like growth factor-I (IGF-I) [12]. Effects of this action are modulated by several other hormones [13]. Some parameters of GH secretion (for example, frequency of $\mathrm{GH}$ peaks, total daily $\mathrm{GH}$ secretion, or $\mathrm{GH}$ response to GHRH stimulation) were associated with higher genetic values in studies comparing $\mathrm{GH}$ secretion of more highly selected and control lines of cattle [14-16], sheep, [17] or pig [18]. On the contrary, Weber et al. [19] recently reported that selection for milk yield in multiparous Holstein cows increased mean $\mathrm{GH}$ and $\mathrm{GH}$ peak height but did not affect $\mathrm{GH}$ peak frequency or IGF-I plasma levels. Furthermore, Klindt [20] found significant negative correlations between GH peak frequency and predicted difference estimates of milk, milk fat, and milk protein yields $(-0.65,-0.42$ and -0.44 , respectively) in a small sample of dairy bulls. In summary, even though numerous researchers concluded that $\mathrm{GH}$ secretion or release could be used as indicator traits in dairy industry, conflicting reported data, probably due to its random nycthemeral synthesis and its moderate repeatibility, make it difficult to propose at the present time $\mathrm{GH}$ measurements in the selection scheme.

\section{Somatocrinin (GHRH) and GHRH receptor polymorphisms}

In the cascade of events that control the pituitary GH secretion, the hypothalamic factor GHRH and its receptor directly control GH synthesis by the somatotrope cells. In 1995, Moody et al. [21] described a restriction fragment length polymorphism (RFLP) in the GHRH gene using the HaeIII restriction enzyme. In a preliminary study on 89 artificial insemination (AI) Holstein-Friesian bulls, we have noted that the rare genotype obtained 
after polymerase chain reaction (PCR)-RFLP HaeIII restriction enzyme (AA, 7.7\%) is significantly favorable for fat percentage and fat yield $(\mathrm{P}<0.01)$. However, this observation must be confirmed on a higher number of animals. Recently, Connor et al. [22] reported a polymorphism at the GHRH receptor gene (located on chromosome 4) using the Eco57I enzyme that could modify GHRH stimulation of the somatotrope cells (E.E. Connor, personal communication, 1998).

\section{Pituitary-specific transcription factor (PIT-1) polymorphism}

Biochemical and ontogenetic studies have shown that Pit-1 is the critical cell-specific transcription factor for activating expression of the prolactin (PRL) and GH genes in the anterior pituitary gland [23]). Pit-1 has subsequently been shown to activate other pituitary genes, including the Pit-1 gene itself [24,25], the GHRH receptor gene [26], the gene coding for the $\beta$ subunit of thyroid-stimulating hormone (TSH) $[27,28]$, and the pituitary $\beta 2$-thyroid hormone receptor [29].

The regulatory regions recognized by Pit- 1 within the PRL, GH, and Pit-1 gene promoters have been demonstrated to be required for appropriate pituitary-specific expression of these genes both in cultured cell lines and transgenic animals [30-32]. In humans, different mutations of the Pit-1 gene have also been reported in patients with hypopituitarism [33] or with sporadic combined pituitary hormone deficiency [34].

Pit-1 is a 291-amino acid protein with a DNA-binding POU domain. This POU domain is characteristic of a family of genes, including Pit-1, Oct-1, Oct-2, and unc-86 [35]. The POU domain is divided into two well conserved regions. The C-terminal half, called the POU-homeodomain, encodes a low affinity DNA-binding domain, whereas the N-terminal half, called the POU-specific domain, confers high affinity of the POU domain and participates in protein-protein interactions [23].

In cattle, Woolard et al. [36] have reported a HinfI RFLP in exon 6 of the Pit-1 gene that has been assigned to chromosome 1 [37]. Digestion of the PCR products with the enzyme revealed two alleles: A (HinfI-) and B (HinfI +$)$. The frequencies of the three genotypes generated by the two alleles in a sample of 89 Italian AI Holstein-Friesian sires were 2.2, 31.5 , and $66.3 \%$ for $\mathrm{AA}, \mathrm{AB}$, and $\mathrm{BB}$, respectively [38]. In this study, fixed and mixed linear models fitted on daughter yield deviations for milk and on deregressed proofs for conformation traits showed a superior effect of allele A for milk $(+73.6 \pm 44.6 \mathrm{~kg} ; \mathrm{P}<0.1)$ and protein yields $(2.93 \pm 1.45 \mathrm{~kg} ; \mathrm{P}<0.05)$, inferior for fat percentage $(-0.038 \pm 0.018 \%$; $\mathrm{P}<0.1)$, and superior for body depth $(0.301 \pm 0.161 ; \mathrm{P}<0.1)$, angularity $(0.235 \pm 0.0 .120$; $\mathrm{P}<0.1)$, and rear leg set $(-0.393 \pm 0.227 ; \mathrm{P}<0.1)$. Recently, an additional study has been realized in our laboratory on 59 AI Holstein bulls commercialized by Semex Alliance (Canada) (unpublished data). In this sample, the frequency of the AA genotype was higher than in the Italian bulls $(13.5 \%$ vs $2.2 \%$; $\mathrm{P}<0.05)$. The frequencies of the two other patterns were, respectively, $37.3 \%$ for $\mathrm{AB}$ and $49.2 \%$ for $\mathrm{BB}$ patterns. The statistical analysis revealed similar associations as for our first study with a significative superiority of the $\mathrm{A}$ allele on the B allele for milk yield $(+222.4 \pm 18.5 \mathrm{~kg} ; \mathrm{P}<0.001)$ and protein yield $(9.17 \pm$ $0.65 \mathrm{~kg} ; \mathrm{P}<0.001)$ but an inferiority for fat yield $(-2.29 \pm 0.51 \mathrm{~kg} ; \mathrm{P}<0.001)$. Finally, 
using multiple marker mapping of QTL for milk production traits on chromosome 1 in Canadian Holstein bulls, Nadesalingam et al. [39] found a QTL affecting the milk and protein yield and suspected a possible linkage with the described Pit-1 polymorphism (J. Nadesalingam, personal communication, 1998).

These preliminary investigations indicate that Pit-1 is a promising new possibility to select for increased protein and milk yield through selection for the A allele. However, this hypothesis must be validated on a large number of animals and for other breeds before definitive conclusions can be made.

\section{Growth hormone polymorphism}

Considering its essential role in lactation processes, the GH gene (associated to chromosome region 19q26-qter in bovine [40]) is a potential target for studies of molecular variation in association with genetic merit of dairy breeds. Using different restriction enzymes, numerous polymorphisms have been reported in bovine species.

Because of an insertion of a $\mathrm{T}$ at position +837 and a $\mathrm{C}-\mathrm{G}$ transition at position +838 , a MspI RFLP is present in the third intron of the bovine GH gene [41]. Høj et al. [42] observed a difference in allele frequencies at the GH loci between two Danish and Norwegian lines, the $M s p I(-)$ haplotype being more frequent in the line selected for milk fat. For Furu et al. [43], the MspI site is located in the intron III and near a transcription factor binding site, and the $M s p I$ ( \pm ) pattern is associated with a $0.9-\mathrm{kb}$ insertion/deletion in the $3^{\prime}$ flanking region potentially carrying transcription regulator sites. For these authors, this polymorphism does not result in differences of indicators for genetic merit in 100 Holstein sires.

With the PCR-RFLP technique using the AluI restriction enzyme, Lucy et al. [44] revealed two alleles responsible for alternative forms of bovine $\mathrm{GH}$ with a Leu or Val residue at position 127. Injection of recombinant bovine $\mathrm{GH}$ with a valine residue corresponding at the Leu/Val polymorphic locus to lactating cows has been shown to improve fat-corrected milk production more than GH-Leu [127] administration [45]. This observation suggests that the Val allele genotype is better for milk production. On the other hand, Lucy et al. [44] reported a significant higher predicted transmitting ability for milk yield for $\mathrm{Val} / \mathrm{Val}$ genotype Jersey cows, but no significant effect was found in their samples of Holstein, Guernsey, Ayrshire, or Jersey bulls. However, Furu et al. [43], Schlee et al. [46], and van der Werf et al. [47] observed no significant effect of the Leu/Val polymorphism on milk trait breeding values of Simmental, Holstein, or Jersey sires.

A third RFLP in the GH using the TaqI restriction enzyme was described in the bovine GH gene by Rocha et al. [48]. In milk production, Falaki et al. [49-50] reported an association between this GH-TaqI polymorphism and milk traits for Simmental cows but not for Holstein-Friesian bulls. The GH-TaqI polymorphism is due to an insertion/deletion of $\approx 1000 \mathrm{bp}$ in the $3^{\prime}$ end of the gene, between the EcoRI and the TaqI restriction site [42,51]. Finally, a positive association of somatotropin gene polymorphism at the exon 5 with selection for milk yield was reported in Holstein cows [52].

In the bovine $\mathrm{GH}$ gene, there are also other variations sites that could be interesting for 
association studies with milk production traits. Hecht and Geldermann [53] have shown seven mutations in the GH gene. Six of them have been identified in the 5'-flanking region and one in the intron I. Some of these variable sites are also potential binding site for trans-acting factors (CAAT/enhancer binding protein, polyoma virus enhancer A binding protein 3, thyroid hormone response element) and therefore possibly are involved in the expression of the growth hormone gene. Recently, Rodrigues et al. [54] identified a polymorphic site in the promoter region of the $\mathrm{GH}$ gene. This polymorphism consists of the absence of an AAG trinucleotide localized 9 nt upstream from the TATAAA sequence. Unfortunately, in these two last studies, the association between production traits and the polymorphism was not examined.

Therefore, it appears that selection for milk production traits based upon conflicting $\mathrm{GH}$ genotype data is not a promising method. The major problem to concluding definitively about the opportunity to select animals on GH genotype is often the limited number of genotyped animals in the published studies.

\section{GH receptor polymorphism}

The cDNA of the bovine transmembrane GHR has been sequenced by Hauser et al. [55]. It consists of 9 coding exons and is associated to chromosome 20 [56]. As deduced from the human nucleotide sequence, the GHR is a protein of 620 aa comprising an extracellular hormone binding domain of 246 aa, a single 24-aa transmembrane region, and a long cytoplasmic domain. The extracellular domain contains seven cysteine residues and five potential N-linked glycosylation sites and two boxes important for the signal transduction after binding of the hormone to its receptor [57,58].

Using the restriction enzymes TaqI, BglII, DraI, EcoRV, HindIII, PstI, and PvuII and hybridization with a heterologous rabbit GHR cDNA probe, Høj et al. [42] did not observe any RFLP for Red Danish calves and Norwegian Red heifers. In opposite to this study and after hybridization with a homologous cDNA probe containing the coding sequence for the intracellular C-terminal part of the receptor, we have identified six restriction enzyme TaqI bands $(7.1,6.2,5.7,5.4,4.2$, and $3.3 \mathrm{~kb})$ that give nine genotypes in Holstein-Friesian AI bulls [49]. The effect of this polymorphism on values for milk protein percentage was highly significant $(\mathrm{P}<0.005)$ and favorable for the rare $(6.6 \%)$ 5.7- and 5.4-kb patterns. An other interesting point of view results in the segregation of a QTL on chromosome 20 reported by Arranz et al. [59] that affects milk yield and composition in a Holstein-Friesian dairy cattle population. The interval bracket by the microsatellites contains the GHR gene. This study identifies at least two QTL alleles, one of which causes an increase in milk volume accompanied by a dilution in fat and in protein concentrations. It would be interesting to correlate the two approaches (candidate gene approach and positioning cloning) in a genetic evaluation of the same herd to determine if the QTL on chromosome 20 is associated with the polymorphism observed for the GHR.

Recently, Moisio et al. [60] detected three variants in the 3'-flanking region of the bGHR: $\mathrm{GHR}_{311}, \mathrm{GHR}_{320}$, and $\mathrm{GHR}_{325}$. The longer alleles $\mathrm{GHR}_{320}$ and $\mathrm{GHR}_{325}$ are more frequent 
in the selected Finnish dairy breeds, whereas the shortest allele $\mathrm{GHR}_{311}$ predominates in the native breeds.

\section{IGF-I and IGF-I receptor polymorphisms}

Mapped on chromosome 5 [61], the IGF-I gene showed a SnaBI polymorphism in the $5^{\prime}$ flanking region [62]. However, in 152 Holstein bulls from selected sires and AI organizations, predicted transmitting abilities for fat, protein, and net merit did not tend to be significantly related to a IGF-I/SnaBI polymorphic form [63]. Moreover, in the same study, it was reported that no SnaBI polymorphism at IGF-I gene and no AluI polymorphism at GH codon 127 interaction effects were detected. Moreover, Ge et al. [62], using the single strand conformational polymorphism method, noted a significant difference in allele frequencies in 76 genotyped Angus cattle from lines selected for high or low blood serum IGF-I concentration that could influence the lactation process. Finally, using the restriction enzymes TaqI, BglII, DraI, EcoRV, HindIII, PstI, PvuII, and hybridization with a heterologous rabbit IGF-I cDNA probe, Høj et al. [42] did not observe any RFLP for Red Danish calves or Norwegian Red heifers.

In 1996, Moody et al. [64] located the IGF-I receptor on bovine chromosome 21. Digestion of IGF-I receptor PCR products with TaqI restriction enzyme revealed a polymorphism with two alleles (A and B). However, these authors concluded that usefulness of this IGF-I receptor polymorphism in studies designed to identify economically important quantitative trait loci in cattle may be limited because of the low B allele frequency and because this allele is only present in Bos indicus cattle. To our knowledge, no new information has been published to validate or dispute this hypothesis.

\section{Conclusions}

One of the obstacles to progress in dairy cattle selection is that milk production traits are expressed only after the first calving. As reported in this mini-review, gene variations at the somatotropic axis could improve the efficiency of dairy industry by an early selection of an interesting animal. Other genes, like genes encoding for milk proteins, PRL and its receptor, the signal transducer and activator of transcription STAT5 that acts in the GH/PRL signal transduction pathway and perhaps presently unknown genes, also could contribute to the progress in genetic selection of farm animals. Before its direct application in dairy farm, this genetic approach requires validation on a sufficient number of animals, but also the development of performant statistical programs for an exact evaluation of the relationships between milk yield and composition and gene variabilities. Moreover, the polygenic control of a production like milk synthesis also limits the direct impact of one unique gene and requires a multigene approach in selection schemes. 


\section{References}

[1] Meuwissen THE, Goddard ME. The use of marker-haplotypes in animal breeding schemes. Genet Sel Evol 1995;28:161-76.

[2] Georges M. Perspectives for marker assisted selection in dairy cattle breeding. In: Welch RAS, Burns DJW, Davis SR, Popay AI, Prosser CG, editors. Milk composition, production, and biotechnology. New York: Cab International, 1997. p. 265-70.

[3] Mackinnon MJ, Georges M. The effects of selection on linkage analysis for quantitative traits. Genetics 1992;4:1177-85.

[4] Kalm E, Reinsch N, Xu N, et al. Mapping quantitative trait loci on cattle chromosome 2, 5, 10, 16, 18 and 23. Anim Genet 1998;29(suppl. 1):62.

[5] Grisart B, Coppieters W, Arranz J-J, et al. QTL mapping on candidate chromosomes 6, 14 and 20 using a red and white cattle grand-daughter design. Anim Genet 1998;29(suppl.1):62.

[6] Heyen DW, Weller JI, Ron M, Band M, Feldmesser E, Da Y, Wiggans GR, Van raden, PM, Lewin HA. Genome scan for QTL influencing milk production and health traits in dairy cattle. Anim Genet 1998; 29(suppl. 1):61.

[7] Grosclaude F. Le polymorphisme génétique des principales lactoprotéines bovines. INRA Prod Anim 1988;1:5-17.

[8] Jakob E. Genetic polymorphism of milk proteins. Bull Int Dairy Fed 1994;298:17-27.

[9] Ng-Kwai-Hang KF, Grosclaude F. Genetic polymorphism of milk proteins. In: Fox PF, editor. Advanced dairy chemistry, Vol. 1. London: Elsevier Science Publishers, 1992. p. 405-55.

[10] Bauman DE. Bovine somatotropin and lactation: from basic science to commercial application. Domest Anim Endocrinol 1999;17:101-116.

[11] Baldi A. Manipulation of milk production and quality by use of somatotropin in dairy ruminants other than cow. Domest Anim Endocrinol 1999;17:131-137.

[12] Chilliard Y. Roles and mechanisms of action of the somatotropin (Growth hormone) in lactating cows. Reprod Nutr Dev 1988;28:39-59.

[13] Renaville R. Somatotropic axis in bovine productions. Contribution to understanding of some endocrine mechanisms involved in growth and lactation. Dissertation thesis, Gembloux Agricultural University, Gembloux, Belgium, 1997. p. 1-142.

[14] Reinecke RL, Barnes MA, Akers RM, Pearson RE. Effect of the selection for milk yield on lactation performance and plasma growth hormone, insulin and IGF-1 in first lactation Holstein cows. J Dairy Sci 1993;76(suppl. 1):286.

[15] Parchury N, Chester-Jones H, Loseth KJ, Wheaton JE, Hansen LB, Ziegler DM, Crabo BG. Somatotropin concentrations in plasma and scrotal circumference in bulls calves with different dairy merit. J Dairy Sci 1993;76:445-52.

[16] Woolliams JA, Angus KD, Wilson SB. Endogenous pulsing and simulated release of growth hormone in dairy calves of high and low genetic merit. Anim Prod 1993;56:1-8.

[17] Dodson MV, Davis SL, Ohlson DC, Ercanbrack SK. Temporal patterns of growth hormone, prolactin and thyrotropin secretion in targhee rams selected for rate and efficiency of gain. J Anim Sci 1983;57:338-42.

[18] Arbona JR, Marple DN, Russel RW, Rahe CH, Mulvaney DR, Sartin JL. Secretion patterns and metabolic clearance rate of porcine growth hormone in swine selected for growth. J Anim Sci 1988;66:3068-72.

[19] Weber WJ, Baumgard LH, Shi Q, Chester-Jones H, Hansen LB, Crooker BA. Effect of selection for milk yield on growth hormone $(\mathrm{GH})$ and insulin-like growth factor-I (IGF-I) profiles in multiparous Holstein cows during the periparturient period. BASE 1998;2(special issue):14.

[20] Klindt J. Relationships among growth hormone and prolactin parameter estimates in Holstein bulls and their predicted differences for lactating traits. J Anim Sci 1988;66:2784-90.

[21] Moody DE, Pomp D, Barendse W. Short communication: restriction fragment length polymorphism in amplification products of the bovine growth hormone-releasing hormone gene. J Anim Sci 1995;73:3789. 
[22] Connor EE, Ashwell MS, Kappes SM, Dahl GE. Characterization of a partial bovine cDNA encoding pituitary growth hormone-releasing hormone receptor (GHRH-R) and mapping of the GH-R to chromosome 4 using a novel PCR-RFLP. BASE 1998;2(special issue):8.

[23] Tuggle CK, Trenkle A. Control of growth hormone synthesis. Domest Anim Endocrinol 1996;13:1-33.

[24] Chen R, Ingraham MA, Treacy MN, Albert VR, Wilson L, Rosenfeld MG. Autoregulation of Pit-1 gene expression mediated by two cis-active promoter elements. Nature 1990;346:583-9.

[25] Rhodes SJ, Chen R, DiMattia GE, Scully KM, Kalla KA, Lin SC, Yu VC, Rosenfeld MG. A tissue-specific enhancer confers Pit-1-dependent morphogen inductibility and autoregulation on the Pit-1 gene. Genes Dev 1993;7:913-9.

[26] Lin C, Lin SC, Chang CP, Rosenfeld MG. Pit-1-dependant expression of the receptor for growth hormone releasing factor mediates pituitary cell growth. Nature 1992;360:765-71.

[27] Haugen BR, Wood WM, Gordon DF, Ridgeway ED. A thyrotrope-specific variant of Pit-1 transactivates the tyrotropin beta promoter. J Biol Chem 268:1993:20818-23.

[28] Steinfelder HJ, Hausser P, Nakayama Y, Radovick S, McClaskey JH, Taylor T, Weintraub BD, Wondisford FE. Thyrotropin-releasing hormone regulation of human TSH $\beta$ expression: role of a pituitary-specific transcription factor (Pit-1/GHF-1) and potential interaction with a thyroid hormone-inhibitory element. Proc Natl Acad Sci USA 1991;88:3130-4.

[29] Wood WM, Dowding JM, Haugen BR, Bright TM, Ridgway EC. Structural and functional characherisation of the genomic locus encoding the murine $\beta$-2 thyroid hormone receptor. Mol Endocrinol 1994;8:1605-14.

[30] Lira SA, Kalla KA, Glass CK, Drolet DW, Rosenfeld MG. Synergistic interactions between Pit-1 and other elements are required for effective somatotroph rat growth hormone gene expression in transgenic mice. Mol Endocrinol 1993;7:694-9.

[31] Lira SA, Crewshaw EB, Glass CK, Swanson LW, Rosenfeld MG. Identification of the rat growth hormone genomic sequences targeting pituitary expression in transgenic mice. Proc Natl Acad Sci USA 1988;85:4755-61.

[32] Crewshaw EB, Kalla K, Simmons DM, Swanson LW, Rosenfeld MG. Cell-specific expression of the prolactin gene in transgenic mice is controlled by synergistic interactions between promoter and enhancer elements. Genes Dev 1989;3:959-64.

[33] Pfäffle RW, Dimattia GE, Parks JS, Brown MR, Wit JM, Jansen M, Van der Nat H, Van den Brande JL, Rosenfeld MG, Ingraham HA. Mutation of the POU-specific domain of Pit-1 and hypopituitarism without pituitary hypoplasia. Science 1992;257:1118-21.

[34] Radovick S, Nations M, Du Y, Berg LA, Weintraub DB, Wondisford FE. A mutation in the POUhomeodomain of Pit-1 responsible for combined pituitary hormone deficiency. Science 1992;257:1115-18.

[35] Herr W, Sturm RA, Clerc RG, Corcoran LM, Baltimore D, Sharp PA, Ingraham HA, Rosenfeld MG, Finney M, Ruvkun G, Harvitz HR. The POU domain: a large conserved region in the mammalian pit-1, oct-1, oct-2 and Caenorhabditis elegans unc-86 gene products. Genes Dev 1988;2:1513-16.

[36] Woollard J, Schmitz CB, Freeman AE, Tuggle CK. Rapid communication: HinfI polymorphism at the bovine Pit1 locus. J Anim Sci 1994;72:3267.

[37] Moody DE, Pomp D, Barendse W. Restriction fragment length polymorphism in amplification products of the bovine Pit-1 gene and assignement of Pit-1 to bovine chromosome 1. Anim Genet 1995;26:45-7.

[38] Renaville R, Gengler N, Vrech E, Prandi A, Massart S, Corradini C, Bertozzi C, Mortiaux F, Burny A, Portetelle D. Pit-1 gene polymorphism, milk yield and conformation traits for Italian Holstein Friesian bulls. J Dairy Sci 1997;80:3431-8.

[39] Nadesalingam J, Plante Y, Gibson JP, Atchinson JL, Wu X. Multiple marker mapping of quantitative trait loci (QTL) for milk production traits on Chromosome 1 in Canadian Holstein bulls. J Dairy Sci 1998; 81(suppl. 1):72.

[40] Hediger R, Johnson SE, Barendse W, Drinkwater RD, Moore SS, Hetzel J. Assignement of the growth hormone gene locus to 19q26-qter in cattle and 11q25-qter in sheep by in situ hybridization. Genomics 1990;8:171-4.

[41] Zhang HM, Brown DR, DeNise SK, Ax RL. Rapid communication: PCR-restriction fragment length polymorphism analysis of the bovine somatotropin gene. J Anim Sci 1993;71:2276.

[42] Høj S, Fredholm M, Larsen NJ, Nielsen VH. Growth hormone gene polymorphism associated with selection for milk fat production in lines of cattle. Anim Genet 1993;24:91-6. 
[43] Furu LM, Kazmer GW, Zinn SA, Rycroft H. Somatotropin MsPI and AluI polymorphisms relative to indicators of the genetic merit of Holstein AI sires. J Anim Sci 1988;76(suppl. 1):75.

[44] Lucy MC, Hauser SD, Eppard PJ, Krivi GG, Clark JH, Bauman DE, Collier RJ. Variants of somatotropin in cattle: gene frequencies in major dairy breeds and associated milk production. Domest Anim Endocrinol 1993;10:325-33.

[45] Eppard PJ, Bentle LA, Violand BN, Ganguli S, Hintz RL, Kung LJ, Krivi GG, Lanza GM. Comparison of the galactopoetic response to pituitary-derived and recombinant-derived variants of the bovine growth hormone. J Endocrinol 1992;132:47-56.

[46] Schlee P, Graml R, Rottmann O, Pirchner F. Influence of growth-hormone genotypes on breeding values of Simmental bulls. J Anim Breed Genet 1994;111:253-6.

[47] Van der Werf JHJ, Verburg FJ, Harders FL, Garssen GJ, te Pas MFW. Influence of genetic variants of bovine growth hormone on milk productivity. BASE, 1998;2(special issue):3.

[48] Rocha JL, Baker JF, Womack JE, Sanders JO, Taylor JF. Statistical associations between restriction fragment lenght polymorphisms and quantitative traits in beef cattle. J Anim Sci 1992;70:3360-70.

[49] Falaki M, Gengler N, Sneyers M, Prandi A, Massart S, Formigoni A, Burny A, Portetelle D, Renaville R. Relationships of polymorphism for growth hormone and growth hormone receptor gene with production traits for Holstein Friesian bulls. J Dairy Sci 1996;79:1446-53.

[50] Falaki M, Prandi A, Corradini C, Sneyers M, Gengler N, Massart S, Fazzini U, Burny A, Portetelle D, Renaville R. Relationships of growth hormone gene and milk protein polymorphisms to milk production traits in Simmental cattle. J Dairy Res 1997;64:47-56.

[51] Hallerman EM, Nave A, Kashy Y, Holzer Z, Soller M, Beckmann JS. Restriction fragment length polymorphism in dairy and beef cattle at the growth hormone and the prolactin loci. Anim Genet 1987;18:213-22.

[52] Lee BK, Lin GF, Crooker BA, Murtaugh MP, Hansen LB, Chester-Jones H. Association of somatotropin (BST) gene polymorphism at the 5th exon with selection for milk yield in Holstein cows. Domest Anim Endocrinol 1996;13:373-81.

[53] Hecht C, Geldermann H. Variants with the 5'-flanking region and the intron I of the bovine growth hormone gene. Anim Genet 1996;27:329-32.

[54] Rodrigues CV, Guimaraes SE, Neto ED, Pinheiro LE. Identification of a novel polymorphism in the promoter region of the bovine growth hormone gene. Anim Genet 1998;29:63-72.

[55] Hauser SD, McGrath MF, Collier RJ, Krivi GG. Cloning and in vivo expression of the bovine growth hormone receptor mRNA. Mol Cell Endocrinol 1990;72:187-200.

[56] Moody DE, Pomp D, Barendse W, Womack JE. Short communication: assignment of the growth hormone receptor gene to bovine chromosome 20 using linkage analysis and somatic cell mapping. Anim Genet 1995;26:341-43.

[57] Leung DW, Spencer SA, Cachianes G, Hammonds RG, Collins C, Henzel WJ. Growth hormone receptor and serum binding protein: purification, cloning and expression. Nature 1987;330:537-43.

[58] Wang YD, Wood WI. Amino acids of the human growth hormone receptor that are required for proliferation and Jak-Stat signaling. Mol Endocrinol 1995;9:303-11.

[59] Arranz J, Coppieters W, Berzi P, Cambisano N, Grisart B, Karim L, Marcq F, Moreau L, Mezer C, Riquet J, Simon P, Vanmnshoven D, Wagenaar D, Georges M. A QTL affecting milk yield and composition maps to bovine chromosome 20: a confirmation. Anim Genet 1998;29:107-15.

[60] Moisio S, Elo K, Kantanen J, Vilki J. Polymorphism within the 3' flanking region of the bovine growth hormone receptor gene. Anim Genet 1998;29:55-7.

[61] Miller JR, Thomsen PD, Dixon SC, Tucker EM, Konfortov BA, Harbitz I. Synteny mapping of the bovine IGHG2, CRC and IGFI genes. Anim Genet 1991;23:51-8.

[62] Ge W, Davis ME, Hines HC. Two SSCP alleles detected in the 5'-flanking region of bovine IGF1 gene. Anim Genet 1997;28:155-6.

[63] Hines HC, Ge W, Zhao Q, Davis ME. Association of genetic markers in growth hormone and insulin-like growth factor-I loci with lactation traits in Holsteins. Anim Genet 1998;29(suppl. 1):63.

[64] Moody DE, Pomp D, Barendse W. Linkage mapping of the bovine insulin-like growth factor-I receptor gene. Mamm Genome 1996;7:168-9. 